\title{
Nalar Maslahat Dalam Kebijakan Zonasi Dan Penguatan Pendidikan Karakter
}

\author{
Firman Muhammad Arif \\ Pascasarjana IAIN Palopo \\ Jl. Agatis Balandai Kota Palopo Sulawesi Selatan Indonesia \\ E-mail: firmanarif@iainpalopo.ac.id
}

\begin{abstract}
Zoning Policy and Character Education Strengthening are government policies in the education sector. Zoning policy aims at efforts to restore national education and strengthen character education aimed at developing religious values which then accelerate the strengthening of individual character so that they are able to control themselves and develop noble character in society and nationhood. Mass reasoning contained in the qawa'id fiqhiyyah and usul al-fiqh is used as an instrument to measure the weight of maslahat contained in government education policies. Zoning policies and strengthening character education are considered as media to achieve goals. The mass content contained in the zoning policy shows maximum weight than the mafsadah (something bad or potentially bad). National education arrangement that prioritizes citizenship character has triggered the government to issue a policy to strengthen character education with the maslahat (something good, potentially good) weight with consideration of the sociological, cultural and political aspects of the local government. The manifestation of strengthening character education is full day school allowing it to be applied in urban school areas and vice versa will increase the heavy burden of parents and students in various schools in rural areas so that full day school is not forced but chosen.
\end{abstract}

Keywords: Dynamic of education, maslahat substance, maslahat weights, Maslahat Values

\begin{abstract}
Abstrak
Kebijakan zonasi dan Penguatan Pendidikan Karakter adalah kebijakan pemerintah dalam bidang pendidikan. Kebijakan zonasi bertujuan sebagai upaya merestorasi pendidikan nasional dan penguatan pendidikan karakter bertujuan untuk pengembangan nilai-nilai agama yang selanjutnya mengakselerasi penguatan karakter individu sehingga mampu mengendalikan diri dan menumbuhkembangkan akhlak mulia dalam bermasyarakat dan berbangsa. Nalar maslahat yang terdapat dalam qawa'id fiqhiyyah dan usul fiqh dijadikan sebagai instrumen untuk menalar maslahat dan mengukur bobot maslahat yang terdapat dalam kebijakan pendidikan dari pemerintah. Kebijakan zonasi dan penguatan pendidikan karakter dinilai sebagai media untuk mencapai tujuan. Kadar maslahat yang terdapat dalam kebijakan zonasi menunjukkan bobot yang maksimal daripada mafsadahnya. Penataan pendidikan secara nasional yang mengedepankan karakter kewarganegaraan memicu pemerintah mengeluarkan kebijakan penguatan pendidikan karakter dengan bobot maslahat yang mempertimbangkan aspek sosiologis, budaya, dan political will pemerintah setempat. Wujud dari penguatan pendidikan karakter adalah full day school memungkinkan diterapkan di kawasan urban school dan sebaliknya akan menambah beban berat orang tua dan siswa di berbagai sekolah yang terdapat di pedesaan sehingga full day school bukan untuk dipaksakan tetapi dijadikan pilihan.
\end{abstract}

Kata Kunci: Dinamika Pendidikan, Substansi Maslahat, Bobot Maslahat, Nilai Maslahat 


\section{Pendahuluan}

Pendidikan adalah media yang menuntun manusia dan tuntunan tersebut dipergunakan untuk mengembangkan nilai, moral dan sikap serta implikasinya (keterlibatan) dalam kehidupannya. ${ }^{1}$ Manusia yang menempuh pendidikan sejak buaian hingga liang lahat akan menjalani kinerja keras, kinerja ikhlas, kinerja cerdas dan kinerja tuntas berkelanjutan. Keterlibatan manusia menjalani pendidikan menuntun manusia untuk memiliki kemampuan yang dapat dipergunakan untuk memutus mata rantai kebiadaban menuju peradaban, keterbelakangan dan kebodohan menuju kemajuan. ${ }^{2}$

Peluang menguasai berbagai kompetensi hanya dapat dilalui dengan pendidikan dan selanjutnya dapat dimanfaatkan untuk beragam kepentingan. ${ }^{3}$ Dengan mengedepankan konsep atau gagasan, memilih nalar kritis-reflektif, dan objektivitas akan berujung pada tingginya nilai seseorang yang berkomitmen pada tradisi keilmuan. ${ }^{4}$ Generasi yang terdidik dengan baik dinilai sebagai generasi yang berpeluang merengkuh passing grade, higher grade bahkan best grade di kalangan masyarakat. Akseptasi dari nilai pendidikan tersebut hanya bisa diwujudkan dengan kinerja keras, cerdas, ikhlas dan tuntas yang berkelanjutan. ${ }^{5}$ Sebuah pepatah Arab menyatakan bahwa manusia akan menjadi pembicaraan bagi generasi berikutnya maka hendaklah manusia menjadi bahan bicara yang bobot kebaikannya untuk manusia.

Pendidikan memobilisasi generasi untuk tidak mengalami stagnasi namun untuk merengkuh kemajuan secara kolektif. Dengan pendidikan maka generasi apapun, kapanpun dan dimanapun akan menikmati dinamika hidup dan bukan beban hidup sehingga manusia baik secara individu maupun kolektif semakin termotivasi melakukan perubahan demi perubahan. ${ }^{6}$ Perubahan yang wajib direalisasikan dalam perspektif Islam sarat dengan "mewujudkan atau meraih maslahat dan menolak mafsadah". ${ }^{7}$

\footnotetext{
${ }^{1}$ H. M. Asrori, Perkembangan Peserta Didik Pengembangan Kompetensi Pedagogis Guru (Cet. I;Yogyakarta: media Akademi, 2015), h. 228

${ }^{2}$ Sutrisno, Integrasi Keilmuan di Era Rovulsi Industri 4.0, Makalah disampaikan pada Kuliah Umum dalam Pembukaan Kuliah Semester Genap 2018-2019 di IAIN Palopo, 20 Februari 2019

${ }^{3}$ Lihat, Jalaluddin, Filsafat Pendidikan Islam: Telaah Sejarah dan Pemikirannya (Cet. II; Jakarta: Kalam Mulia, 2011), h. 105

${ }^{4}$ Lihat, Moh. Sabri AR, Mewaspadai Gejala Anti Intelektualisme, Koran Harian Pagi Fajar Makassar pada Rubrik Semesta Tanda, tanggal 23 Februari 2018, h. 8.

${ }^{5}$ Lihat, Aan Arizany, Berkaca pada Konsep Pendidikan Bapak Bangsa, Koran Seruya pada Rubrik Opini tanggal 24 Juli 2016, h.6

${ }^{6}$ Jan Hendrik Raper, Pengantar Logika Asas-asas Penalaran Sistematis (Yogyakarta: Kanisius, 2016), h. 8 .

${ }^{7}$ Izz al Din bin Abdu al Salam, Qawa"id al AHkam fi Masalih al Anaam (al Qahirah: Dar al Istiqamah, 1980), Juz I, h. 11
} 
Keluarga, sekolah dan masyarakat sebagai wujud tri pusat pendidikan tidak bisa dilepaskan dalam dinamika kehidupan manusia. ${ }^{8}$ Keluarga menempati posisi pertama karena kehadiran manusia bermula dari "kerjasama" kedua orang tuanya. ${ }^{9}$ Kerjasama yang dimaksudkan dalam hal kerjasama keras (usaha maksimal dengan menghidupi, merawat, mengasuh), mendidik dan membentuknya menjadi manusia dengan nilai ketuhanan dan nilai kemanusiaan. ${ }^{10}$

Fitrah manusia ditentukan oleh keluarganya dan prioritasnya adalah ketetapan teologi dogma berwujud akidah dan kepercayaan. Kata fitrah adalah kata yang viral, ramai diucapkan dan berarti suci, murni, kodrati atau alami/natural. ${ }^{11}$ Salah satu ayat dalam al-Qur'an dan sering diucapkan dalam pembukaan salat sebelum membaca al Fatihah adalah Firman Allah subhanahu wa'ta'ala:

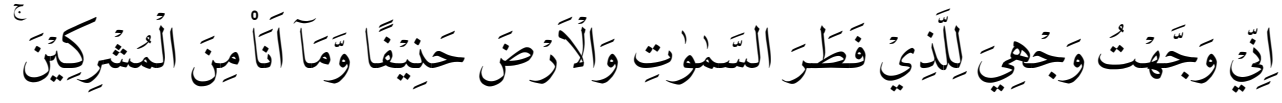

Terjemahnya:

Sesungguhnya aku menghadapkan diriku dengan lurus (hanif) kepada Dzat yang menciptakan (fathara) langit dan bumi, dan aku bukanlah orang-orang yang menyekutukan Tuhan. (al-An'am/6: 79).

Dalam maqasid al syari'ah atau tujuan hukum Islam biasanya diwujudkan dalam bentuk hifzu al din atau penjagaan agama sebagai pondasi yang harus ditanamkan sejak dini dan dilanjutkan dengan nilai jiwa, akal, keturunan, dan harta. ${ }^{12}$ Agama atau al-din, dalam paradigma Alquran tidak hanya sekedar ragam perkara kehidupan setelah mati namun agama sebagai pedoman/tuntunan untuk terwujudnya kebahagiaan manusia ${ }^{13}$ di dunia, termasuk mengajarkan ilmu pengetahuan melalui pendidikan. ${ }^{14}$

Persepsi tentang manusia dalam Islam dipandang sebagai tubuh, akal dan hati nurani karena proses pembentukan manusia dilandaskan

\footnotetext{
${ }^{8}$ Lihat, Jalaluddin, Filsafat Pendidikan Islam: Telaah Sejarah dan Pemikirannya, h. 121-132.

${ }^{9}$ Lihat, Jujun S. Suriasumantri, Ilmu dalam Perspektif Sebuah Kumpulan Karangan tentang Hakekat Ilmu (Cet. XIV; Jakarta: Yayasan Obor Indonesia, 1999), h. 41

${ }^{10}$ Lihat, Republik Indonesia, Undang-Undang Ri Nomor 20 Tahun 2003 tentang Sistem Pendidikan Nasional Bab II Pasal 2.

${ }^{11}$ Lihat, Dawam Rahardjo, Ensiklopedi Al-Qur"an Tafsir Sosial Berdasarkan Konsep-konsep Kunci (Cet. I; Jakarta: Paramadina, 1996), h. 39.

${ }^{12}$ Lihat, Amir Syarifuddin, Garis-garis Besar Fiqh (Cet. I; Jakarta: Prenada Media, 2003), h.2

13 14Lihat, Muhammad bin Salih al Utsaimin, al Qawa ${ }^{e e}$ id al Fiqhiyyah (al Iskandariyyah: Dar al Basirah, 1422 H), h. 19. Kaidah yang dimaksudkan adalah الدين جاء لسعادة البشر والانتفاء الثر عنهم والضرر

14 15Lihat, Dawam Rahardjo, Ensiklopedi Al-Qur'an Tafsir Sosial Berdasarkan Konsepkonsep Kunci, h. 540.
} 
dari anatomi manusia yang sejalan dengan salah satu ayat al-Qur'an seperti dalam al Mulku: 23, al Nahl: 78, dan al Mu'minun: 78 yang diawali dari alsam'u (pendengaran), al-basar (penglihatan) dan selanjutnya al-afidata (qalbu atau hati). ${ }^{15}$ Kata al sam'u berarti pendengaran yang mewakili indera manusia yang secara tekstual berwujud telinga. Adapun kata al basar berarti penglihatan atau indera mata dan secara maknawi (kontekstual) diartikan pengamatan, observasi dan telaah. Berikutnya dengan kata al- af'idata yang berarti hati atau qalbu. Pernyataan ayat tersebut menunjukkan adanya hierarki. ${ }^{16}$

Keluarga menjadi pondasi yang mengawali proses pendidikan dan dilanjutkan dengan kehadiran sekolah sebagai media pembelajaran yang menjembatani antara keluarga dan masyarakat. Seberapa pentingnya sekolah bagi manusia tidak bisa dipungkiri sepanjang kehidupan manusia. Pendidikan adalah proses mendewasakan manusia, ${ }^{17}$ investasi jangka panjang dan kehadirannya bukan hanya memberikan pendidikan formal tetapi juga informal dan semi formal. Dasar-dasar ilmu pengetahuan diajarkan di tingkat dasar dan dilanjutkan atau diupgrade ke tingkat keahlian tertentu, biasanya di tingkat sekolah kejuruan, institut bahkan perguruan tinggi meskipun ada beberapa kasus bahwa pengetahuan tidak selalu didapatkan dari institusi pendidikan.

Orang yang putus sekolah namun sukses adalah cerminan adanya kemampuan belajar dari pengalaman sendiri dan pengalaman orang lain. Kondisi tersebut diartikan seseorang putus sekolah namun tidak putus pendidikannya sehingga keberhasilan diraih dengan self informed (belajar sendiri), self discipline (disiplin diri) dan tidak pernah putus harapan. Ketiga sifat tersebut ditemukan dalam diri orang yang memiliki insight (persepsi), modal pemahaman yang jelas akan situasi yang kompleks, berintuisi mendalam dan akrab dengan introspeksi namun dalam realitasnya tidak semua orang memilikinya.

Keberlanjutan pendidikan di sekolah diiringi dengan akseptasi orang tua yang menginginkan anaknya mendapat pendidikan layak dari sekolah yang dinilai mampu memberikan pendidikan dan pengajaran yang unggul. $^{18}$ Menempuh pendidikan di sekolah untuk mengupgrade kemampuan dan kapabilitas peserta didik, dari membaca, menulis, dan

\footnotetext{
15 16Zadeh Fu'ad Abdu al Baqi, Fathu al Rahman li Talib al Qur'ean (Cet. I; Beirut: Dar al Ilmi, $1323 \mathrm{H})$

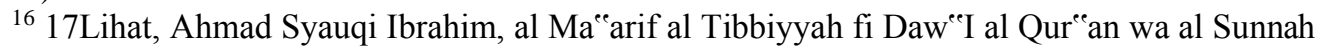
Juz I (Cet. I; al Qahirah: Dar al Fikr al 'Arabiy, 2002 M/1423 H), h. 115-116

${ }^{17}$ Lihat, Zakiah Daradjat, Kepribadian Guru (Jakarta: Bulan Bintang, 2000). H. 10. Lihat pula, Heri Jauhari Muchtar, Fikih Pendidikan (Cet. III; Bandung: Remaja Rosdakarya, 2012), h. 1

${ }^{18}$ Lihat, Heri Jauhari Muchtar, Fikih Pendidikan, h. 121
} 
memecahkan berbagai masalah ilmu pengetahuan didapatkan di lembaga pendidikan. Pengajaran tentang berperilaku dalam situasi yang berbeda, proses meningkatkan harga diri, cara menyesuaikan dalam tantangan hidup dan masa depan usaha yang nanti akan menjadi pilihan untuk memperbaiki taraf hidup secara umum didapatkan di lembaga pendidikan. ${ }^{19}$

Materi ajar yang disampaikan bukan sekadar matematika, bahasa, dan lainnya tetapi juga tuntunan berinteraksi yang nantinya akan dipraktikkan dalam kehidupan sosial. Kesadaran akan tanggung jawab sosial membentuk peserta didik lebih dewasa dalam menghadapi berbagai perkara. Peluang menstimulus peserta didik dengan bakat dan keterampilan akan semakin terasah sehingga mampu mewujudkan cita dan harapan. Semua hal tersebut hanya bisa dilalui dengan kesabaran, tekad, dedikasi yang tinggi, dan menikmati proses pembelajaran.

Arah pendidikan di Indonesia secara umum masih bertumpu pada akses pendidikan dimana profil sekolah harus bisa menunjukkan sumber daya pendidik dan fasilitas yang memadai. Hak asas mendapatkan pendidikan harus terpenuhi dalam keadaan apapun dengan menawarkan berbagai alternatif. ${ }^{20}$ Integritas, kompetensi dan potensi harus dimiliki oleh guru sehingga mampu memberikan kemajuan untuk bangsa dalam menghadapi tantangan global, perkembangan laju teknologi dan ilmu pengetahuan sehingga tidak terpinggirkan dalam persaingan di dunia pendidikan. ${ }^{21}$

Salah satu indikator dari kemajuan negara dengan memberikan akses dan pelayanan pendidikan yang layak kepada warga negaranya. Pada negara-negara maju, pendidikan adalah akar dari segala persoalan yang mendapat perhatian khusus dari seluruh pihak dengan dijadikannya sebagai fokus utama sehingga sistem pendidikan diharapkan berjalan dan mencetak hasil seperti yang diharapkan. Untuk itulah, maka alokasi dana, kualitas perekrutan serta perawatan fasilitas pada aspek pendidikan sangat diperhatikan. ${ }^{22}$

\footnotetext{
${ }^{19}$ Hayati, Pentingnya Peran Keluarga dan Masyarakat pada Pendidikan Anak di Sekolah, diakses via kompasiana.com pada tanggal 18 Februari 2019

20 Retno Listyarti sebagai Komisioner Komisi Perlindungan Anak Indonesia Bidang Pendidikan, Kisruh dan Polemik Kebijakan Zonasi dalam Penerimaan Peserta Didik Baru, Sumber Kompas TV dalam acara Sapa Malam Indonesia, Juli 2018

${ }^{21}$ Nursalam, Guru dan Peradaban Pendidikan Indonesia, Harian Fajar Rubrik Opini pada tanggal 1 Maret 2017, h. 6

22 Jessica, Negara-negara Maju dan Sistem Pendidikan yang Diterapkan, diakses educenter.id. pada tanggal 21 Februari 2019
} 
Sistem pendidikan seharusnya bergerak dengan fleksibel dan bervariasi, dimana siswa diberikan ragam pilihan yang bertujuan memenuhi kepentingan dan cara belajar yang berbeda. Tanggung jawab pemerintah terkait pendidikan diramaikan dengan kebijakan untuk meningkatkan kualitas hidup melalui wajib belajar, melakukan revolusi karakter bangsa, memperteguh ke-bhineka-an, dan memperkuat restorasi sosial Indonesia. ${ }^{23}$ Kebijakan pemerintah terkait pendidikan adalah pertimbangan yang didasarkan atas sistem nilai dan beberapa penilaian berbagai faktorfaktor yang bersifat situasional. Dengan pertimbangan tersebut selanjutnya dijadikan sebagai dasar mengoperasikan pendidikan yang bersifat melembaga. ${ }^{24}$

\section{Metode}

Artikel ini ditulis berdasarkan hasil penelitian kualitatif deskriptif dengan pendekatan fikih pendidikan atau fiqh tarbawi dan fokus utamanya dengan mengeksplorasi berbagai realitas yang berkenaan dengan kebijakan zonasi dan penguatan pendidikan karakter yang dicetuskan pada masa Menteri Pendidikan Muhadjir Effendi era Jokowi - Jusuf Kalla. Kebijakan pendidikan yang lain seperti Ujian Nasional Berbasis Komputer dan Uji Kompetensi Guru tidak masuk dalam tulisan karena kebijakan UNBK adalah kebijakan yang bersifat lanjutan dan di dalam pelaksanaannya selalu ada diiringi dengan evaluasi, pembenahan dan modifikasi. Begitupun dengan Uji Kompetensi Guru adalah kebijakan yang berkenaan dengan kualitas dan kompetensi tenaga pendidik dan bukan untuk peserta didik.

Artikel yang didasarkan dengan mengurai hasil riset kualitatif deskriptif dan menggunakan instrumen yang ada dalam fiqh of legal maxim atau yang biasa disebut dengan qawa'id fqhiyyah. Keberadaan qawa'id fiqhiyyah dibatasi dalam beberapa kaidah yang berkenaan dengan nilai perubahan dan nilai maslahat. Praktik kebijakan zonasi dan penguatan pendidikan karakter dianalisis dengan mengamati realitanya di lapangan yang bersumber dari berbagai media informasi baik dari koran, artikel online, pengamatan nyata di tengah masyarakat, website pemerintah dan sumber yang bisa dipercaya.

Proses eksplorasi fokus dimulai dengan brainstorming terhadap masalah penerapan zonasi dan penguatan pendidikan karakter di tengah masyarakat. Adapun langkah berikutnya, kebijakan zonasi dan penguatan pendidikan karakter dielaborasi, dianalisis dan diintegrasikan dengan

${ }^{23}$ Tim Liputan6, Nawacita Pemerintah Jokowi-JK Terkait Pendidikan, diakses liputan6.com tanggal 21 Februari 2019

${ }^{24}$ Ali Imran, Implementasi Kebijakan Pendidikan (Jakarta: Bumi Aksara, 2008). 
mempertautkan kaidah-kaidah perubahan dan mashalat yang terdapat dalam qawa'id fiqhiyyah. ${ }^{25}$

\section{Menakar Dinamika Kebijakan Pendidikan Dengan Nalar Maslahat}

Pembangunan manusia secara kolektif dipelopori dengan menyelenggarakan pendidikan secara paripurna dan hanya dapat diwujudkan oleh guru dengan perannya sebagai pelaku estafet pelaksanaan cita-cita pembangunan bangsa. Kinerja keras, cerdas, dan ikhlas guru sebagai pendidik menuntun generasi selanjutnya dan dituntut menjadi pusat kebudayaan, pengembangan ilmu dan nilai ilmu. ${ }^{26}$ Kesiapan pendidik ditunjukkan dengan berkemampuan memproduksi bahan ajar yang selanjutnya dijadikan sebagai suluh penerang bagi peserta didik. ${ }^{27}$

Akseptasi tersebut akan dicapai jika ada keterlibatan pemerintah untuk memformulasikan kebijakan yang sarat dengan nilai pendidikan. Kebijakan pendidikan seringkali disinonimkan dengan politik, program, keputusan, undang-undang, aturan, regulasi, keputusan, kesepakatan, konvensi, dan rencana strategis. ${ }^{28}$ Fikih tarbiyah terdiri dari dua kata yaitu fikih dan tarbiyah (pendidikan). Eksistensi fikih tidak dapat disangkal dari posisi sentralnya sejak abad ke 2 Hijriah. Fikih terlahir dari sebuah dinamika pergulatan kehidupan masyarakat sebagai jawaban solusi atas problematika aktual. ${ }^{29}$

Antara fikih dan realitas masyarakat termasuk pendidikan memiliki hubungan yang tidak terpisahkan yang saling mempengaruhi satu sama lain. ${ }^{30}$ Analisis tersebut mengantar pada asumsi, bahwa fikih dapat dikembangkan dan salah satunya dengan fikih pendidikan atau tarbiyah

\footnotetext{
${ }^{25}$ Beberapa terapan pendidikan yang dipertautkan dengan Fiqh of Legal Maxim yang telah dihadirkan ulama salaf pada masa kemajuan atau masa perkembangan mazhab dan aliran jukum Islam. Lihat, 'Abdullah bin Salih bin Muhammad al Buhaniyah, al Tatbiqat al Tarbawiyyah li Ahammi al Qawa ${ }^{e e}$ ad Fiqhiyyah al Kubra (Saudi: al Imam Muhammad bin Saud al Islamiyyah University, 2007 M/1428 H). Lihat, Nur al Din Mukhtar al Khadmi, Qawae id Fiqhiyyah (Tunis: Zaytunah University, 2007).

${ }^{26}$ M. Fadlan L Nasurung, Belajar dari Pesantren, Opini Koran Fajar Harian Pagi Makassar terbit 29 Desember 2018, h. 6

${ }^{27}$ Lihat, Aan Arizany, Berkaca pada Konsep Pendidikan Bapak Bangsa, Sumber Koran Seruya pada Rubrik Opini tanggal 24 Juli 2016, h. 6

${ }^{28}$ Lihat, Muhammad Rifa'I, Sosiologi Pendidikan Struktur dan Interaksi Sosial di dalam Institusi Pendidikan (Cet. I; Jogjakarta: Ar Ruzz Media, 2011), h. 4

${ }^{29}$ Lihat, Mujiono Abdullah, Dialektika Hukum Islam dan Perubahan Sosial , Sebuah Refleksi Sosiologis atas Pemikiran Ibnu Qayyim al Jauziyyah (Cet. I; Surakarta: Muhammadiyah University Press, 2003), h. 1

${ }^{30}$ Wael B. Hallaq, A History of Islamic Legal Theories, diterjemahkan oleh Kusnadiningrat dan Abdul Haris dengan judul: Sejarah Teori Hukum Islam (Jakarta: RajaGrafindo Persada, 2000), h. 1-23.
} 
dan fikih siyasah dengan pertimbangan bahwa perubahan tersebut harus sejalan dengan perkembangan dan perubahan ruang dan waktu yang mengitarinya. ${ }^{31}$ Kata pendidikan bermakna sebagai proses mendewasakan manusia atau upaya untuk "memanusiakan" manusia dan melalui pendidikan maka manusia tumbuh dan berkembang secara wajar dan sempurna sehingga dapat melakukan tugasnya sebagai manusia. ${ }^{32}$

Begitupun dengan fikih siyasah sebagai produk hukum Islam yang objek pembahasannya tentang kekuasaan atau kebijakan yang apabila disederhanakan meliputi hukum tata negara, hukum ekonomi, dan hukum pendidikan. Dilihat dari aspek keterkaitannya maka fikih siyasah membahas hubungan rakyat dan pemerintah sebagai penguasa yang konkret di dalam ruang lingkup pemerintahan termasuk didalamnya kebijakan pendidikan. ${ }^{33}$ Salah satu kaidah fikih dalam aspek kebijakan yang dianggap sinergi dengan berbagai kebijakan pemerintahan dan dianggap penting untuk diketahui, yaitu:

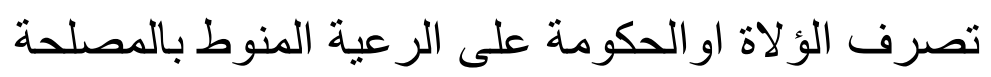

Artinya: Kebijakan pemimpin atau pemerintah terhadap rakyatnya bergantung kepada kemaslahatan. ${ }^{34}$

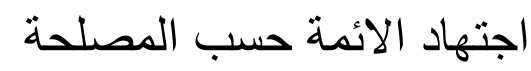

Artinya: Keputusan dari kalangan pemimpin ditakar berdasarkan maslahat. ${ }^{35}$

Ketegasan yang terdapat dalam kaidah ini adalah adanya nilai tuntunan, tuntutan dan tontonan (penampilan, pesona baik yang menyulut perhatian) bahwa kebijakan yang dikeluarkan menjadi regulasi yang menuntun terwujudnya kepentingan masyarakat. Kaidah ini bersifat menuntut pemimpin dalam pemerintahan manapun supaya berkemampuan menunjukkan kebijakan yang berorientasi kemaslahatan

\footnotetext{
${ }^{31}$ Lihat, Achmad Musyahid Idrus, Perkembangan Penalaran Filosofis Hukum Islam (Cet. I; Makassar: Alaluddin University Press, 2013), h. 33

${ }^{32}$ Heri Jauhari Muchtar, Fikih Pendidikan (Cet. III; Bandung: Remaja Rosda Karya, 2012), h. 1

${ }^{33}$ Lihat, Djazuli, Kaidah-Kaidah Fikih, Kaidah-Kaidah Hukum Islam dalam Menyelsaikan Masalah- masalah Yang Praktis (Cet. III; Jakarta: Kencana Prenada Media,2006), h.147

${ }^{34}$ Fauzi Usman Salih, al Qawa"id wa al Dawabit al Fiqhiyyah wa Tatbiqatiha fi al Siyasah al Syar"iyyah (Riyad: Dar al 'Asimah, 2011), h. 175. Lihat pula, Imam Tajuddin 'Abd. Al-Wahab al-Subki, al-Asybah wa al-Naza"ir (Cet. I; Beirut: Dar al Kutub al Ilmiyyah, 1399 H/1979 M), h. 134.

${ }^{35}$ Bakr bin Abdullah Zaid, al Qawa"id al Fiqhiyyah al Mustakhrajah min Kitab I"lam al Muwaqqi"in li Al Allamah Ibnu al Qayyim al Jauziyyah (Dimasyq: Dar Ibnu 'Affan, 2000 M), h. 439
} 
rakyat bukan mengikuti keinginan hawa nafsu, keluarga bahkan kelompoknya.

Kaidah tersebut menegaskan bahwa citra, nama dan viralnya sebuah pemerintah serta kebijakannya patut diamati dan dinilai hasilnya apakah menunjukkan adanya dukungan atau sebaliknya Kaidah tersebut dikuatkan dan diintegrasikan dengan teks dan substansi yang terdapat dalam Alquran di surah an-Nisa': 58 sebagai tuntunan, panutan dan petunjuk. ${ }^{36}$ Negara dengan bentuk apapun, formula dan ideologinya tentu tidak bisa dilepaskan dari kritikan publik meskipun kritikan tersebut ada yang destruktif, konstruktif, bersifat semu atau transparansi. Jika kebijakan dan pelaksanaannya tersebut tidak akurat maka akan menyulut meluasnya ketidakpuasan karena dihegemoni oleh mafsadah (keburukan). Namun jika kebijakan tersebut mengindikasikan maslahat (perbaikan, kebaikan) maka akan mengundang dukungan luas dan mengarah pada perubahan yang fundamental. ${ }^{37}$

Formula keputusan yang tepat memerlukan informasi yang memadai seperti penguasaan, materi, sikap dan perilaku proporsional yang selanjutnya diapresiasi atau konsekuensinya. ${ }^{38}$ Perumusan kebijakan dengan menempuh sejumlah proses yang baik akan terintegrasi ke dalam semua bagian yang berhubungan dengan sistem sosial. ${ }^{39}$ Pencapaian hak asasi setiap warga dipandang penting dengan menempatkan manusia dengan kodrat, harkat dan martabatnya. Kodrat adalah keseluruhan sifat asli manusia yang menempatkannya sebagai makhluk sosial. Harkat manusia adalah nilai manusia yang memiliki cipta, rasa dan karsa, kebebasan, hak-hak dan kewajiban asasi. Martabat manusia adalah kedudukan luhur yang menuntun dan menuntut manusia berakal budi. Derajat manusia adalah kodrat tingkat kedudukan yang memiliki bakat untuk pencapaian derajat yang mulia. ${ }^{40}$

Pencapaian paripurna tersebut hanya bisa direalisasikan dengan menyelenggarakan pendidikan. ${ }^{41}$ Setiap warga negara berhak memperoleh pendidikan bermutu sesuai dengan minat dan bakat alami tanpa diiringi 137

36 'Abd al-Wahab al Khallaf, al-Siyasah al Syar"iyyah (al-Qahirah: Dar al Ansar, 1977 M), h.

${ }^{37}$ Lihat, Michael Rush Philip Althoff, An Introduction to Political Sociology, dialihbahasakan oleh Kartini Kartoni dengan judul: Pengantar Sosiologi Politik (Cet. X; Jakarta: RajaGrafindo Persada, 2003), h. 117

${ }^{38}$ Kusaeri Suprananto, Pengukuran dan Penilaian Pendidikan (Cet. II; Yogyakarta: Graha Ilmu, 2016), h. 3

${ }^{39}$ Ali Imran, Implementasi Kebijakan Pendidikan (Jakarta: Bumi Aksara, 2008).

${ }^{40}$ Soerapto, Cita Negara Pancasila, Dmokrasi dan Hak Asasi Manusia (Jakarta: FH-UI, Dokumentasi Presentasi Makalah Seminar Sehari 26 Januari 1995).

${ }^{41}$ Lihat, Subandi al-Marsudi, Pancasila dan UUD"45 dalam Paradigma Reformasi (Cet. II; Jakarta; RajaGrafindo Persada, 2001), h. 99-101. 
diskriminasi dalam bentuk apapun seperti status sosial, status ekonomi, suku, kasta, etnis, agama, dan gender.42 Pendidikan menjamin keberpihakan semua peserta didik meskipun memiliki hambatan fisik maupun mental, hambatan ekonomi, hambatan sosial, maupun kendala geografis dengan penyediaan layanan pendidikan dan aksesbilitas.

Perubahan sosial yang berlangsung begitu cepat di berbagai bidang kehidupan berpotensi menjadi masalah bagi semua institusi sosial dan pendidikan dan kebijakan pendidikan. ${ }^{43}$ Berbagai kebijakan dari pemerintah dinilai penting untuk dibahas secara komprehensif dan salah satunya adalah kebijakan pendidikan. Beberapa pihak ada yang memandang negatif bahwa dunia pendidikan menjadi salah satu penyebab ketidakstabilan bangsa karena dinilai gagal melahirkan generasi penerus yang berjati diri, berkarakter, cerdas secara kognitif, afektif, dan psikomotorik, bersikap santun, bertakwa, punya toleransi tinggi, berintegritas, mandiri, berdikari, dan demokratis termaktub menjadi satu dalam kesatuan kepribadian. ${ }^{44}$

Kesungguhan pemerintah dalam menangani pendidikan sudah tercermin sejak awal kemerdekaan. Belum genap setahun pasca kemerdekaan dibentuklah Kementerian Pendidikan dan Pengajaran. Selanjutnya diiringi dengan melahirkan berbagai regulasi seperti UndangUndang Nomor 4 Tahun 1950 tentang Dasar Pendidikan dan Pengajaran yang kemudian dimodifikasi dan dibenahi hingga sekarang adanya Undang-Undang No, 20 Tahun 2003 yang juga diiringi seperangkat Peraturan Pemerintah. ${ }^{45}$

Pendidikan menjadi prioritas utama dan andalan utama meningkatkan kualitas sumber daya manusia guna menghadapi dunia yang kompetitif. Pendidikan pasca kemerdekaan belum sepenuhnya menjadi prioritas utama akibat adanya kesenjangan dalam kualitas manusia. Kegaduhan politik masa Soekarno dinilai telah memarginalkan pendidikan akibat adanya perang fisik, diplomasi menghadapi Belanda, arogansi politisi yang berakibat pada jatuh bangunnya kabinet, kegaduhan

${ }^{42}$ Haidar Putra Daulay, Pendidikan Islam dalam Sistem Pendidikan Nasional di Indonesia (Cet. I; Jakarta: Prenada Media, 2004), h. 195

${ }^{43}$ Lihat, Muhammad Rifa'I, Sosiologi Pendidikan Struktur dan Interaksi Sosial di dalam Institusi Pendidikan, h. 5

${ }^{44}$ Lihat, Mujamil Qomar, Kesadaran Pendidikan Sebuah Penentu Keberhasilan Pendidikan (Cet. I; Jogjakarta: Ar Ruzz Media, 2012), h. 6

${ }^{45}$ Haidar Putra Daulay, Pendidikan Islam dalam Sistem Pendidikan Nasional di Indonesia, h. 194. 
legislator dalam setiap sidang yang selalu dead lock, hingga adanya G-30 S PKI.

Prioritas Pemerintah Orde Baru berkaitan dengan pembangunan bertumpu pada pertumbuhan ekonomi. Superioritas pembangunan ekonomi menjadikan pendidikan semakin inferior sehingga berdampak pada berbagai hal yang bernuansa KKN serta krisis ekonomi dan moneter. Adapun era reformasi ditandai dengan era globalisasi yang berujung pada tuntutan akselerasi kualitas manusia dengan melakukan pengarusutamaan ${ }^{46}$ potensi bangsa kepada sektor pendidikan termasuk di dalamnya kebijakan pendidikan. ${ }^{47}$

Dalam tulisan ini akan dibahas kebijakan berkaitan pendidikan dengan menggunakan nalar maslahat yang terdapat ilmu usul fiqh dan qawa'id fiqhiyyah sebagai instrumen untuk mengeksplorasi kebijakan pendidikan dalam pemerintahan. Eksistensi syariah tidak lain untuk merealisasikan maslahat dan menolak mafsadah (kerusakan). ${ }^{48}$ Kerja manusia diapresiasi karena muatan didalamnya bernilai maslahat atau dimarginalkan karena berpotensi mafsadah. Setiap maslahat memiliki tingkatan tertentu tentang kebaikan dan manfaat serta pahalanya dan setiap mafsadah juga memiliki tingkatan-tingkatannya. 49

Pembukaan Undang-Undang Dasar Republik Indonesia 1945 sebagai teologi konstitusi telah mengamanahkan pemerintah untuk mencerdaskan kehidupan bangsa. ${ }^{50}$ Pemerintah berkewajiban menjamin pemerataan kesempatan dan meningkatkan mutu pendidikan. ${ }^{51}$

Pendidikan dalam aspek psikomotorik, afektif, dan kognitif menjadi fokus pemerintah dengan memprioritaskan ranah afektif sebagai aspek yang mendominasi pembentukan karakter manusia mulia dan berbudi pekerti yang tinggi. ${ }^{52}$

Pemerintahan Jokowi - JK dari tahun 2014 hingga 2019 berbagai kebijakan yang terkait dengan pendidikan telah dirumuskan. Bias dari

\footnotetext{
${ }^{46}$ Pengarusutamaan diartikan sebagai proses membntuk ide, gagasan dan nilai yang diterima luas oleh masyarakat. Lihat, Badan Pengembangan dan Pembinaan Bahasa, Kamus Besar Bahasa Indonesia (Jakarta: Kementerian Pendidikan dan Kebudayaan Republik Indonesia, 2000

${ }^{47}$ Lihat, Mohammad Saroni, Pendidikan untuk Orang Miskin Membuka Kran Keadilan dalam Kesempatan Berpendidikan (Cet. I; Jogjakarta: Ar Ruzz Media, 2013), h. 107-122

${ }^{48}$ Lihat, Izzuddin bin 'Abd al Salam, Qawa"id al-Ahkam fi Masalih al Anam Juz I (t.t.: Dar al Jail, 1980), h. 11

49 Al-Ghazali, al-Mustasfa min „Ilmi al Usul (Mesir: t.pn. tt.), h. 2. Lihat pula, Izzuddin bin Abd al Salam, Qawa"id al Ahkam fi Masalih al Anam, h. 11

${ }^{50}$ Lihat, Republik Indonesia, Pembukaan UUD 1945 dalam salah satu alineanya.

${ }^{51}$ Haidar Puta Daulay, Pendidikan Islam dalam Sistem Pendidikan Nasional di Indonesia, h. 193.

${ }^{52}$ Muhammad as Said, Filsafat Pendidikan Islam (Cet. I; Jakarta; Mitra Pustaka, 2011), h. 135
} 
kebijakan tersebut terkait pada level pendidikan dasar dan menengah namun minim yang berkenaan dengan pendidikan tinggi. Pembahasan dalam tulisan ini diorientasikan terhadap kebijakan yang menuai apresiasi atau dinilai ada stigma yang berdampak terhadap peserta didik dan masa pemerintahan tertentu. ${ }^{53}$ Dengan alasan tersebut maka kebijakan Bantuan Operasional Sekolah (BOS) dan Uji Kompetensi Guru (UKG) atau kebijakan semacamnya tidak dibahas.

Berikut ulasan dan nalar dari dua kebijakan pemerintah tentang kebijakan zonasi dan penguatan pendidikan karakter yang dinilai populer di masa pemerintahan Jokowi-JK periode 2014-2019 sebagai berikut:

\section{A. Kebijakan Sistem Penerimaan Peserta DidikBaru (PPDB) dengan Zonasi}

Penerapan kebijakan zonasi didasarkan adanya regulasi Peraturan Menteri Pendidikan dan Kebudayaan No. 14 Tahun 2018 tentang Penerimaan Peserta Didik Baru (PPDB) untuk TK, SD, SMP, SMA, dan sederajat. Kebijakan zonasi mewajibkan peserta didik bersekolah di zona sekitar tempat tinggal mereka. ${ }^{54}$ Radius dalam sistem zonasi ditetapkan oleh pemerintah setempat sesuai dengan kondisi di daerah tersebut dengan memperhatikan ketersediaan daya tampung sekolah sebagaimana yang termaktub dalam pasal 13.55 Penetapan radius zona melibatkan musyawarah/kelompok kerja kepala sekolah sehingga penentuan kebijakan zonasi dinilai bersifat lokal dan atas konsensus kolektif.

Sebelum pemberlakuan kebijakan zonasi, penerimaan peserta didik baru diprioritaskan pada Nilai Evaluasi Murni (NEM) yang berakibat hadirnya stigma favorit dan non favorit. Sekolah favorit cenderung memiliki sarana dan fasilitas yang lebih baik dari sekolah non favorit. ${ }^{56}$ Keberadaan sekolah favorit yang menampung komunitas siswa yang pintar terkesan lebih superior dan homogen. Adapun siswa sekolah non favorit cenderung menjadi inferior dengan sarana dan prasarana yang kurang memadai dan berdampak psikologis sehingga menimbulkan sekat-sekat psiko-sosial antar sekolah. ${ }^{57}$

\footnotetext{
${ }^{53}$ Lihat, Firda Olivia, Lima Kebijakan Pendidikan yang Pernah Jadi Kontroversi, diakses dari sumber brilio.net pada tanggal 16 Maret 2019

${ }^{54}$ Estu Suryowati, Tiga Kebijakan di Bidang Pendidikan yang Dikritik oleh Federasi Serikat Guru, Sumber nasional.kompas.com diakses pada 21 Februari 2019

${ }^{55}$ Kementerian Pendidikan dan Kebudayaan, Peraturan Menteri Pendidikan dan Kebudayaan Republik Indonesia No. 14 Tahun 2018 Pasal 3, Kemendikbud RI, 2018

${ }^{56}$ Muhammad Rifa'I, Sosiologi Pendidikan Struktur dan Interaksi Sosial di dalam Institusi Pendidikan (Cet. I; Jogjakarta: ar Ruzz Media, 2011), h. 115

${ }^{57}$ Nurul Ilmi Idrus, Gaduh Zonasi, Sumber Koran Harian Pagi Fajar Makassar pada Rubrik Opini tanggal 17 Juli 2018, h. 6.
} 
Kesenjangan antar sekolah semakin kuat karena ketimpangan kualitas guru antara sekolah favorit dan tidak favorit yang tidak bisa dihindari. Aktualisasi diri peserta didik mengalami lambatnya pertumbuhan, bias perbedaan fenomena psikologis semakin nyata di tengah masyarakat dan indikasi neorosis (gangguan kejiwaan) dalam wujud penyakit sosial dimungkinkan dapat terjadi. ${ }^{58}$

Guru di sekolah favorit dinilai punya status sosial lebih tinggi dan punya kualitas yang lebih baik dibandingkan guru yang ada di sekolah pinggiran. ${ }^{59}$ Keadaan inilai yang berakibat pada pencapaian 8 standar pendidikan sulit untuk direalisasikan karena adanya stigma favorit dan tidak favorit. Ketimpangan lainnya juga memunculkan rotasi antar guru yang tidak sehat antar sekolah. Guru yang ada di sekolah non favorit dinilai mengalami downgrade atau penurunan kualitas begitupun sebaliknya ${ }^{60}$ sehingga kreativitas pendidik tidak mengalami peningkatan karena peserta didiknya yang homogen. ${ }^{61}$

Sekolah favorit cenderung lebih banyak mendapatkan bantuan bukan hanya dari pemerintah tapi juga dari masyarakat terutama dari orang tua peserta didik yang anaknya bersekolah di sekolah favorit. ${ }^{62}$ Dengan adanya donasi individu atau kolektif tersebut maka popularitas sekolah favorit semakin melejit dan akselerasi ketersediaan sarana dan prasarana bukan hanya bersifat kuantitatif tetapi juga semakin berkualitas. Kenyataan tersebut semakin memperkuat paradigma masyarakat untuk berlomba memasukkan anaknya ke sekolah yang berlabel favorit.

Dalam perkembangannya, rivalitas yang terjadi antara orang tua peserta didik bukan hanya berdampak psikologis dan suburnya sekatsekat psiko-sosial namun juga pada cara pandang orang tua peserta didik untuk menghalalkan segala cara supaya anaknya diterima di sekolah berlabel favorit. Rivalitas yang baik adalah menempuh cara-cara yang halal untuk mencapai tujuan dan bukannya menghalalkan segala cara untuk mencapai tujuan. Cara pandang masyarakat yang selama ini berkembang

\footnotetext{
${ }^{58}$ Hendro Setiawan, Manusia Utuh Sebuah Kajian Atas Pemikiran Abraham Maslow (Cet. IV: Yogyakarta: Kanisius, 2014), h. 74-75

${ }^{59}$ Nursalam, Guru dan Peradaban Pendidikan Indonesia, Opini harian Pagi Surat Kabar Fajar tanggal 1 Maret 2017, h. 6

${ }^{60}$ Susianah Afandy, Polemik Sistem Zonasi PPDB di Sekolah, Narasumber dan Komisioner KPAI Bidang Pendidikan di Berita Satu TV, tanggal 11 Juli 2018.

${ }^{61}$ Nurul Ilmi Idrus, Gaduh Zonasi, Sumber Koran Harian Pagi Fajar Makassar pada Rubrik Opini tanggal 17 Juli 2018, h. 6

${ }^{62}$ Muhadjir Effendy, Polemik Sistem Zonasi PPDB di Sekolah, Narasumber dan Menteri Pendidikan dan Kebudayaan RI Masa Pemerintahan Jokowi - Jusuf Kalla di Berita Satu TV, tanggal 11 Juli 2018
} 
telah menyuburkan peluang terjadinya pungutan liar, hutang budi dari orang tua peserta didik yang berkategori ekonomi menengah atas, gratifikasi atau tindakan amoral lainnya semakin masif dan viral. ${ }^{63}$

Adapun sekolah dengan label non favorit atau sekolah pinggiran bukan hanya terpinggirkan lokasi dan statusnya tetapi juga mengalami perlambatan pengembangan sarana, fasilitas, dan minim kepedulian dari pemerintah dan masyarakat. Beberapa peneliti ada yang menilai bahwa pendidikan bermutu didominasi oleh masyarakat dengan kategori ekonomi menengah atas. ${ }^{64}$ Interaksi sosial antar peserta didik ditunjukkan dengan adanya dikotomi favorit dan non favorit sehingga terkesan ada diskriminasi daripada persamaan dan mempertajam perbedaan daripada merajut keakraban. ${ }^{65}$

Kebijakan lama dinilai telah memunculkan beragam ketimpangan lintas sekolah, ketidakmerataan peserta didik yang menumpuk di sekolah tertentu dan kesenjangan status antar sekolah padahal kontras diskriminasi sangat melekat dalam pelayanan pendidikan, sekat-sekat sosial yang tidak sehat semakin subur dan disharmoni dalam dunia pendidikan semakin masif sehingga terobosan pemerintah dihadirkan dalam bentuk kebijakan zonasi untuk merevolusi tata manajemen pendidikan secara nasional, meminimalisir ketimpangan spesial, anomali struktural- kultural tersebut di kalangan masyarakat. ${ }^{66}$

Kebijakan zonasi dilakukan untuk menyikapi, merespon dan mengeliminasi kebiasaan- kebiasaan lama yang keliru. Substansi pendidikan dalam agama dan regulasi negara tetap dipertahankan dengan melakukan inovasi kebijakan yang mengarah pada perubahan yang fundamental. Berikut kaidah fikih ${ }^{67}$ yang sejalan dan mendukung kebijakan zonasi:

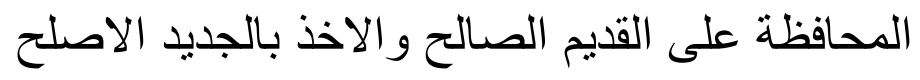

\footnotetext{
${ }^{63}$ Thamrin Karman, Menakar Sistem Zonasi, sebagai Narasumber dan Sesditjen Dikdasmen Kemendikbud RI pada Kompas TV 21 Mei 2018

${ }^{64}$ Muhadjir Effendy, Polemik Sistem Zonasi PPDB di Sekolah, Narasumber dan Menteri Pendidikan dan Kebudayaan RI Masa Pemerintahan Jokowi - Jusuf Kalla di Berita Satu TV, tanggal 11 Juli 2018

${ }^{65}$ Asrori, Perkembangan Peserta Didik Pengembangan Kompetensi Pedagogis Guru (Cet. I; Yogyakarta: Media Akademia, 2015), h. 142

${ }^{66}$ Ridwan Situmorang, Mendukung Kebijakan Zonasi, Opin di Harian Pagi Surakt Kabar Palopo Pos pada tanggal 9 Juli 2018, h. 4.

${ }^{67}$ Jaih Mubarok, Kaidah Fiqh - Sejarah dan Kaidah Asasi (Cet. I; Jakarta: RajaGrafindo Persada, 2002), h.104
} 
Artinya: Menjaga hal-hal atau sesuatu yang dianggap lama dan masih baik dan mengambil atau mengadopsi sesuatu yang baru yang sifat dan muatannya lebih baik

Kualitas akademik sangat mungkin dinilai dan diukur oleh orang lain namun lain halnya dengan karakter yang tidak seorangpun bisa menilai secara maksimal karena dibatasi oleh ruang dan waktu. Kata "al qadim al salih" menunjukkan karakter (pembiasaan dan keteladanan) dan penilaiannya dilakukan secara pribadi dengan bantuan orang lain. Penilaian kualitas karakter berbeda dengan penilaian akademis dimana penilaian akademis lebih mengutamakan hasil akhir sedang penilaian karakter tidak akan pernah menafikan proses yang dijalani selama pembelajaran. ${ }^{68}$

Pendidikan karakter sarat dengan keteladanan dan pembiasaan sebagai penopang utama sehingga al-qadim al-salih atau penopang utama tersebut sebagaimana diungkapkan dalam kaidah tersebut mutlak untuk dijaga dan dipertahankan namun yang berubah hanya media dan triknya dengan wujud melakukan inovasi kebijakan. Ketimpangan berkelanjutan tidak patut dipertahankan karena potensi kegaduhan sudah terlihat dalam langkah awal di proses pendaftaran dan polemik yang berkelanjutan.

Dengan adanya kebijakan zonasi maka stigma favorit dan tidak favorit akan punah dengan sendirinya, kesenjangan antar sekolah terminimalisir, sinergisitas antara sekolah dan orang tua terbangun karena dekatnya lembaga pendidikan dengan tempat tinggal peserta didik serta rivalitas tergantikan dengan pemerataan secara struktural dan kultural.69 Kebijakan zonasi diperlukan untuk pemetaan perlu atau tidaknya pembangunan sekolah negeri baru yang dinilai belum memadai, membuka bobroknya ketimpangan penempatan guru yang belum lengkap dan kesenjangan bantuan sarana dan

prasarana sehingga semua sekolah punya peluang yang sama untuk mencapai 8 standar mutu pendidikan secara merata dan tidak lagi diskriminatif. 70

\footnotetext{
${ }^{68}$ Dalasari Pera, Menilai Pendidikan Karakter, Opini Harian Pagi Fajar Makassar terbit tanggal 13 Oktober 2018, h. 6.

${ }^{69}$ Muhadjir Effendy, Polemik Sistem Zonasi PPDB di Sekolah, Narasumber dan Menteri Pendidikan dan Kebudayaan RI di Berita Satu TV, tanggal 11 Juli 2018

${ }^{70}$ Yudhistira Massardi, Polemik Sistem Zonasi dalam PPDB, sebagai Narasumber dan Pemerhati Pendidikan EDUSPEC Indonesia di Berita Satu TV, tanggal 11 Juli 2018.
} 
Salah satu kaidah fikih yang berkenaan dengan media ${ }^{71}$ dan menunjukkan bahwa kebijakan zonasi adalah instrumen/alat atau media yang mengarah terealisasinya sebuah tujuan sebagai berikut:

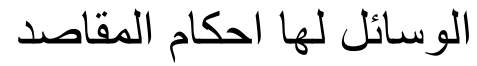

\section{Artinya: Bagi Media berlaku hukum-hukum tujuan (pokok). ${ }^{72}$}

Kebijakan zonasi diasumsikan seperti al wasa'il atau media dan ditinjau dari aspek kontennya merupakan senjata ampuh yang mendisrupsi berbagai ketimpangan dalam sistem yang lama. Dari aspek konteksnya maka kebijakan zonasi selama diberlakukan atau diterapkan perlu dievaluasi secara berkelanjutan karena ketersediaan sekolah negeri di berbagai wilayah belum sepenuhnya merata sehingga pemerintah melakukan penyamarataan fasilitas dan kualitas pendidikan. ${ }^{73}$ Disrupsi ketimpangan lama yang mengakar dan upaya berkelanjutan untuk pemerataan fasilitas dan kualitas pendidikan diasumsikan sebagai maqasid.

Beberapa kaidah fikih lainnya yang sejalan dengan kebijakan zonasi adalah:

\section{مالايدرك كله لايترك كله}

Artinya: Apa yang tidak bisa dilaksanakan seluruhnya, maka jangan ditinggalkan seluruhnya.

Keputusan mengeluarkan kebijakan zonasi didukung dan patut dilaksanakan meskipun dalam pelaksanaannya menuai hambatan sehingga kebijakan zonasi tersebut tidak berarti harus ditinggalkan seluruhnya. Akan tetapi, kebijakan zonasi tersebut dalam tatanan normatif dan praktiknya dapat dilaksanakan dan diterapkan sesuai dengan adanya peluang mewujudkan nilai maslahat dan mereduksi mafsadah dan potensinya dalam kebijakan tersebut. ${ }^{74}$

Idealitas sebuah kebijakan yang dikeluarkan pemerintah dinilai telah menunjukkan bobot maslahat yang maksimal atau bobot mafsadah-

${ }^{71}$ Lihat, Abu Muhammad Izz al Din Abdu al Aziz ibnu Abdi al Salam, Qawa"id al Ahkam fi Masalih al Anaam (Mesir: al Istiqamah, t.th.), Juz I, h. 46. Lihat, Jaih Mubarok, Kaidah Fiqh Sejarah dan Kaidah Asasi (Cet. I; Jakarta: RajaGrafindo Persadad, 2002), h. 68.

${ }^{72}$ Bakr bin Abdullah Zaid, al Qawa ${ }^{e e} i d$ al Fiqhiyyah al Mustakhrajah min Kitab Ieclam al Muwaqqiee in li Al Allamah Ibnu al Qayyim al Jauziyyah (Dimasyq: Dar Ibnu 'Affan, 2000 M), h. 337

${ }^{73}$ Nurul Ilmi Idrus, Gaduh Zonasi, Sumber Koran Harian Pagi Fajar Makassar pada Rubrik Opini tanggal 17 Juli 2018, h. 6

${ }^{74}$ Muhammad Mustafa al Zuhailiy, al-Qawa"id al Fiqhiyyah wa Tatbiqatuha ala al Mazahib al „Arba"ah Juz II (Dimasyq: Dar al Fikr, 2006 M/1427 H), h. 4 
nya (keburukan. kerusakan) yang dinilai minimal. ${ }^{75}$ Salah satu kaidah fikih yang sejalan dengan kebijakan pemerintah tersebut adalah:

$$
\text { لايجوز استدعاء البلاء }
$$

Artinya: tidak diperkenankan mengundang atau memancing munculnya masalah dan bencana. ${ }^{76}$

Kehidupan yang dijalani manusia, baik secara pribadi maupun kolektif dipastikan secara aklamasi menyepakati untuk menghindari bahaya jika memungkinkan atau meminimalisir bahaya jika sudah berhadapan dengan bahaya tersebut. Namun dalam kondisi dihadapkan dengan multi bahaya maka manusia dituntut untuk melalui bahaya yang porsinya lebih ringan dan minimal daripada melalui bahaya yang takarannya lebih besar atau maksimal. ${ }^{77}$

\section{B. Kebijakan Penguatan Pendidikan Karakter (PPK)}

Penguatan pendidikan karakter adalah bagian dari implementasi Nawacita Presiden Joko Widodo-Jusuf Kalla dalam sistem pendidikan nasional. Penguatan pendidikan karakter diamati secara singkat adalah kebijakan politis namun secara substansial merupakan kebijakan progresif yang dinilai mampu mengakselerasi kualitas pendidikan di tanah air. Dalam arti lain, penguatan pendidikan karakter meskipun beberapa kalangan ada yang menilainya bersifat politis namun mengarah pada politis normatif.

Kebijakan PPK terintegrasi dalam Gerakan Nasional Revolusi Mental yaitu perubahan cara berpikir, bersikap, dan bertindak lebih baik. Nilai-nilai utama dari penguatan pendidikan karakter adalah religius, nasionalis, mandiri, gotong royong, dan integritas. Nilai-nilai tersebut ditanamkan direvitalisasi dan dipraktikkan melalui sistem pendidikan nasional agar diketahui, dipahami dan diterapkan di seluruh sendi kehidupan di sekolah dan masyarakat. ${ }^{78}$

Perkembangan otak manusia mencapai sekitar $50 \%$ saat balita dan sekitar $80 \%$ saat berumur 8 tahun. Pada saat itu, pembentukan watak, sifat, dan kepribadian anak juga berkembang seiring dengan pertumbuhan

\footnotetext{
${ }^{75}$ Bakr bin Abdullah Zaid, al Qawa"id al Fiqhiyyah al Mustakhrajah min Kitab I"lam al Muwaqqi"in li Al Allamah Ibnu al Qayyim al Jauziyyah (Dimasyq: Dar Ibnu 'Affan, 2000 M), h. 375

${ }^{76}$ Fauzi Usman Salih, al Qawa"id wa al Dawabit al Fiqhiyyah wa Tatbiqatiha fi al Siyasah al Syar"iyyah, h.121

${ }^{77}$ Fauzi Usman Salih, al Qawa"id wa al Dawabit al Fiqhiyyah wa Tatbiqatiha fi al Siyasah al Syar"iyyah,h.70

${ }^{78}$ Octen Suhadi, Penguatan Pendidikan Karakter (PPK) untuk Guru dan Siswa SMA/MA (Cet. I; Jakarta Erlangga, 2018), h. 3
} 
fisiknya. Oleh karena itu, upaya menumbuhkan karakter positif sedini mungkin dilakukan. ${ }^{79}$

Salah satu faktor yang mempengaruhi perkembangan kualitas generasi bangsa adalah keluarga sebagai pondasi dan sumber menanamkan karakter positif. Keluarga memiliki peran yang dominan dan sentralistik dalam menimba pengembangan diri. Tanggung jawab sekolah melanjutkan dan memposisikan diri sebagai mediator dengan mengupayakan penguatan pendidikan karakter. Kebijakan penguatan pendidikan karakter atau disingkat PPK tidak lain untuk mengupayakan sinergitas tri pusat pendidikan, yaitu keluarga, sekolah, dan masyarakat. Peran keluarga dan ibu secara khusus dinilai sebagai sekolah pertama bagi peserta didik. ${ }^{80}$

Orang tua di keluarga menuntun anak dengan menanamkan karakter berwujud nilai agama dan nilai interaksi sosial dan guru di sekolah menguatkan karakter peserta didik sehingga tercipta komunikasi secara berulang dan terus menerus yang nantinya akan melahirkan generasi dengan perilaku volisional. ${ }^{81}$ Fungsi volisional adalah fungsi kehendak yang artinya fungsi memilih dan memutuskan, atau perilaku yang dipertimbangkan dengan penuh kesadaran atas segala konsekuensi positif dan negatifnya. ${ }^{82}$ Nilai agama dengan totalitas mengikuti ajaran agama meniscayakan peserta didik untuk mengembangkan akalnya yang selanjutnya dielaborasi dengan pengembangan intelegensi sosial dan intelegensi emosional.

Kebijakan tersebut menuntut lembaga pendidikan untuk mempersiapkan peserta didik secara keilmuan dan kepribadian dengan wujud soliditas nilai-nilai moral, spiritual, dan keilmuan. ${ }^{83}$ Dalam Islam, kewajiban orang tua dalam mendidik anak telah diatur secara struktural dan kultural. Fikih pendidikan merumuskan pendidikan keluarga terhadap anak dari proses kejadian, pertumbuhan dan perkembangan manusia, memberikan tuntunan dalam mendidik, mengarahkan terwujudnya tuntutan pendidikan (prosedur pendidikan) yang paripurna, dan

\footnotetext{
${ }^{79}$ Mujahidin, Pelibatan Masyarakat untuk Pembelajaran Bermutu, Opini dipublikasi di Harian Palopo Pos, tanggal 2 Mei 2016, h. 4

${ }^{80}$ Tariq Ra'uf Mahmud, al Ummu Madrasatu Iza A"dadtaha - A"dadta Sya"ban Tayyiba al A"raq. Diakses dari artikel yang bersumber dari kitabat@kitabat.com pada tanggal 22 Maret 2019.

${ }^{81}$ Adriansyah Irawan, Mulai Pendidikan dari Keluarga, Opini dipublikasi di Palopo Pos tanggal 10 Juli 2018, h. 4.

${ }^{82}$ Ronal W. Leigh, Effective Christian Ministry, diterjemahkan oleh Stephen Suleeman dengan judul: Melayani dengan Efektif (Cet. VII; Jakarta: Gunung Mulia, 2007), h. 34.

${ }^{83}$ Kementerian Pendidikan dan Kebudayaan RI, Kebijakan Penguatan Pendidikan Karakter, diakses cerdasberkarakter.kemendikbud.go.id pada tanggal 9 Maret 2019
} 
akhirnya menampilkan atau mempertontonkan produk pendidikan berwujud manusia yang berbudi luhur atau berakhlak karimah. ${ }^{84}$

Pernyataan sastrawan Ahmad Syauqi menegaskan keberadaan ibu sebagai pilar pendidikan generasi selanjutnya dengan pernyataannya sebagai berikut: 85

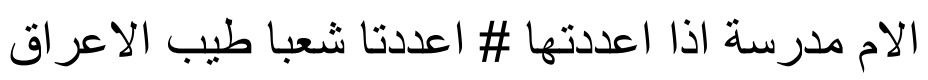

Artinya: Ibu adalah pendidikan pertama bagi anaknya jika dipersiapkan dengan baik maka sama halnya dalam ini dinilai telah mempersiapkan generasi yang kuat.

Eksistensi ibu dalam keluarga memiliki tanggung jawab besar dalam lingkungan keluarga yang mewarnai pola pikir dan pola zikir (ibadah) anaknya. Peran ayah ikut berkontribusi dalam keluarga dengan memposisikan diri sebagai "surga" dan teladan dalam lingkungan keluarga Pro kontra yang terjadi dalam kebijakan tersebut tereliminasi dengan Peraturan Presiden No. 87 tahun 2017 dalam Pasal 9 yang mengatur setiap sekolah diberi kebebasan untuk membuat aturan sekolah lima hari atau enam hari. ${ }^{86}$ Kebijakan PPK bukan kebijakan yang bersifat represif (menekan, mengekang, menahan, atau menindas) tetapi bersifat persuasif (membujuk, merangkul, mendekap, upaya meyakinkan dengan melakukan pendekatan). Kondisi tersebut dapat dinilai dari nama kebijakan tersebut yaitu penguatan pendidikan karakter bukan memposisikan untuk menanamkan pendidikan karakter.

Kebijakan penguatan pendidikan karakter dalam lingkungan sekolah dinilai sebagai upaya untuk menjembatani penanaman pendidikan karakter yang dijalankan keluarga atau orang tua peserta didik. Berbagai langkah seperti persiapan pembelajaran, upaya peserta didik dalam belajar, kemampuan pendidik dalam mengajar, proses pembelajaran yang efektif dan metode pengajaran yang baik akan menghasilkan kualitas pendidikan sehingga anak bukan hanya memiliki modal intelektual tetapi juga modal spiritual (nilai agama) dan modal sosial (kemampuan interaksi sosial).

${ }^{84}$ Lihat, M. Thalib, 25 Asas Islami Mendidik Anak (Bandung: Irsyad Baitu al Salam, 2001), h. 10-21. Lihat, Heri Jauhari Muchtar, Fikih Pendidikan (Cet. II; Bandung: Remaja Rosda Karya, 2012), h. 59-119.

${ }^{85}$ Samiyah Manisi, al Uтmи Madrasatun U"la, Makalah diakses dari alukah.net pada tanggal 22 Maret 2019

${ }^{86}$ Presiden RI, Peraturan Presiden No, 87 Tahun 2017 tentang Penguatan Pendidikan Karakter Pasal 9 ayat 1-3, Jakarta: Lembaran Negara RI, September 2017. 
Guru sebagai pilar utama dalam pendidikan formal tidak bisa dilepaskan dari realitas adanya beragam persoalan internal dan eksternal. Peserta didik dalam lingkungan sekolah yang tidak sepenuh hati menyerap seluruh materi akademis biasanya memiliki beban masalah sosial ekonomi keluarga yang ikut berangkat (berpengaruh dan mempengaruhi) ke sekolah. Bidang akademik dipastikan tidak akan tertangani dengan baik karena mental dan kepribadian siswa yang rapuh. Bibit ilmu yang dipersiapkan guru kepada peserta didik akan berakibat pada kurang atau tidak mendapat respon karena beban dari rumah mempengaruhi proses pendidikan di lingkungan sekolah.

Konstruksi pembinaan pendidikan karakter bermula dari ketahanan keluarga dan kebijakan penguatan pendidikan karakter di sekolah diposisikan dalam ranah mereformasi moral peserta didik. ${ }^{87}$ Dalam ranah qawa'id fiqhiyyah dinilai sebagai alat atau media yang mendukung peran keluarga yang menanamkan pendidikan karakter. Kaidah fikih yang sejalan dengan kebijakan pemerintah tersebut adalah:

$$
\text { الوسائل لها احكام المقاصد }
$$

Artinya: Berbagai media atau alat yang digunakan status hukumnya sama dengan tujuan. ${ }^{88}$

Kebijakan penguatan pendidikan karakter dinilai sebagai alat dan penanaman pendidikan karakter yang dijalankan keluarga peserta didik. Pendidikan karakter adalah pilar kebangkitan bangsa dengan sub tema "raih prestasi, junjung tinggi budi pekerti". Signifikansi pendidikan karakter tidak bisa dinafikan dan sangat menentukan kemajuan peradaban bangsa, tidak hanya unggul tapi juga cerdas. Keunggulan pemikiran dan kehebatan karakter menjadi penentu kemajuan bangsa. Kedua jenis keunggulan tersebut hanya dapat dibangun dan sehingga ibu mampu berperan maksimal dan sepenuh hati menjalankan kewajibannya. ${ }^{89}$

Kebijakan Penguatan Pendidikan Karakter (PPK) adalah ekstraksi dari filosofi Bapak Pendidikan Ki Hajar Dewantara dengan olah karsa, olah

\footnotetext{
${ }^{87}$ Abdullah bin Salih bin Muhammad Albuhaniyyah, al Tatbiqat al Tarbawiyyah li Ahammi al Qawa"id al Fiqhiyyah al Kubra (2007 M/1428 H), h. 101-107

${ }^{88}$ Bakr bin Abdullah Zaid, al Qawa"id al Fiqhiyyah al Mustakhrajah min Kitab I"lam al Muwaqqi"in li Al Allamah Ibnu al Qayyim al Jauziyyah (Dimasyq: Dar Ibnu 'Affan, 2000 M), h. 337

${ }^{89}$ Zadeh Fu'ad Abdu al Baqi, Fathu al Rahma Li Talibi Ayat al Qur"an (Bandung: Penerbit Diponegoro, 2010) Beberapa surah dalam al-Qur'an menjelaskan tentang peran keluarga: Surah al-Baqarah; 233, Luqman; 12-14, Luqman; 17-19. Lihat pula, Muhammad bin Ismail al Bukhari, Sahih al Bukhari Jilid VII, Kitab al Adab Bab tentang Mendekap dan Merangkul Anak (Beirut: Dar al Kutub al Ilmiyyah, t.th), Hadis Nomor 6003, h. 100.
} 
hati, olah pikir, olah raga yang selanjutnya diberikan paying hukum dalam bentuk Permendikbud No. 75 tahun 2016 tentang Komite Sekolah, Permendikbud No. 23 tahun 2017 tentang Hari Sekolah, Peraturan Pemerintah No. 19/2017 tentang Guru dan Perpres No. 87 tahun 2017 tentang PPK. ${ }^{90}$ Terbitnya regulasi Perpres No. 87.2017 sebagai payung hukum yang nilainya lebih tinggi dari sebelumnya dan mempertegas kebijakan full day school dengan lima hari sekolah atau delapan jam belajar per hari. ${ }^{91}$

Pada mulanya, kebijakan full day school menuai polemik di masyarakat, baik yang mendukung atau menggugat. Dari aspek positifnya maka kebijakan tersebut dapat meminimalisir anak dari kecanduan gadget ${ }^{92}$ dan adapun aspek negatifnya maka dinilai sebagai upaya mempolitisasi kebijakan pendidikan dan adanya kekhawatiran akan "mematikan" Madrasah Diniyyah yang jam belajarnya hanya sore sehingga dikhawatirkan anak tidak lagi memiliki waktu untuk belajar agama. ${ }^{93}$

Kebijakan penguatan pendidikan karakter dinilai sebagai alat dan penanaman pendidikan karakter yang dijalankan keluarga peserta didik. Pendidikan karakter adalah pilar kebangkitan bangsa dengan sub tema "raih prestasi, junjung tinggi budi pekerti". Signifikansi pendidikan karakter tidak bisa dinafikan dan sangat menentukan kemajuan peradaban bangsa, tidak hanya unggul tapi juga cerdas. Keunggulan pemikiran dan kehebatan karakter menjadi penentu kemajuan bangsa. Kedua jenis keunggulan tersebut hanya dapat dibangun dan dikembangkan melalui pendidikan. Sasaran pendidikan bukan hanya kepintaran dan kecerdasan, tetapi juga moral, budi pekerti, watak, nilai, kepribadian yang tangguh, dan mulia.

Sasaran dan tujuan pendidikan tersebut menjadi kewajiban maka media menuju kepada yang wajib juga menjadi wajib dengan sendirinya. Sebaliknya apabila yang dituju tersebut adalah haram, maka usaha menuju yang haram juga dinilai haram. Sebagai contoh, apabila babi itu haram maka menyelenggarakan peternakan babi juga dinilai haram bagi orang Islam. Apabila menutup aurat itu wajib, maka mengusahakan pabrik tekstil

\footnotetext{
${ }^{90}$ Doni Koesoema, Kebijakan Penguatan Pendidikan KarakterKementrian Pendidikan dan Kebudayaan, presentasi makalah dalam pertemuan nasional MNKP di Malang 6 Oktober 2017.

${ }^{91}$ Supriatin dan Rizki Andwika, Jokowi Teken Perpres Pengganti Peraturan Full Day School, diakses merdeka.com pada tanggal 7 Maret 2019.

${ }^{92}$ Fahri Hamzah, Full Day Sekolah Meminimalisir Anak Kecanduan Gadget, diakses merdeka.com pada tanggal 7 Maret 2019

${ }^{93}$ Marsudi Syuhud, Full Day School dikhawatirkan “matikan” Madrasah Diniyyah, diakses merdeka.com pada tanggal 7 Maret 2019.
} 
untuk menutup aurat dalah wajib. ${ }^{94}$ Demikian pula dengan pendidikan karakter dinilai sebagai suatu kewajiban maka kebijakan penguatan karakter sebagai media atau sarananya otomatis menjadi wajib pula.

Berkenaan dengan kebijakan penguatan pendidikan karakter maka keluarga diposisikan sebagai sumber, dasar, pondasi menanamkan pendidikan karakter tersebut. Keberadaan sekolah menjadi penyambung dalam menanamkan nilai karakter dengan melakukan penguatan pendidikan karakter dengan wujud regulasi, aturan, payung hukum, perangkat hukum, cara/prosedur, media atau alat. Kebijakan full day school yang digalakkan Kementerian Pendidikan dan Kebudayaan bukan untuk dipaksakan dengan pertimbangan sosiologi masyarakat yang heterogen.

Kebijakan full day school tidak untuk digeneralisasikan karena sekolah urban dan non urban punya distingsi tersendiri sehingga kebijakan ini dijadikan sebagai opsi yang tidak mengikat atau bersifat voluntary dan tergantung kesediaan dan kesiapan setiap sekolah di berbagai daerah. Adapun kebijakan full day education atau pendidikan dilakukan sepenuh hari karena merupakan norma yang mengikat dalam hidup manusia.

Adapun penilaian dari sebuah kebijakan, apakah dinilai baik atau buruknya suatu prosedur sangat bergantung pada tujuan. Kaidah fikih yang dinilai menyinggung tentang kebijakan tersebut adalah:

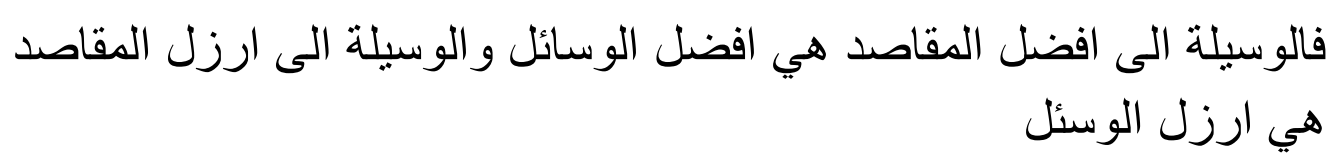

Artinya: Cara (media) yang menuju kepada tujuan yang paling utama adalah seutama-utamanya cara, dan cara yang menuju kepada tujuan yang paling hina adalah seburuk-buruknya cara.

Kaidah yang disebutkan diatas bersumber dari kaidah usul al fiqh karena merupakan kaidah yang berkenaan dengan cara istinbat atau penetapan (fath zari'ah dan sadd zari'ah) hukum dan kalangan fuqaha memasukkannya sebagai kaidah fikih. ${ }^{95}$ Dengan demikian maka kebijakan penguatan karakter adalah media dan prosedur yang dinilai sebagai

${ }^{94}$ Djazuli, Kaidah-Kaidah Fikih - Kaidah-kaidah Hukum Islam dalam Menyelesaikan Masalah-masalah yang Praktis (Cet. III; Jakarta: Kencana Prenada Media, 2010 ), h. 31

${ }^{95}$ Djazuli, Kaidah-Kaidah Fikih - Kaidah-kaidah Hukum Islam dalam Menyelesaikan Masalah-masalah yang Praktis, h. 32-33 
kebijakan yang tidak sepenuhnya buruk atau baik. Kontroversi terhadap kebijakan full day school sarat terjadi di lingkungan pedesaan dan keselarasan terhadap kebijakan tersebut lebih cocok diterapkan di kawasan perkotaan.

Kebijakan penguatan pendidikan karakter dinilai sebagai kebijakan yang status hukumnya menjadi wajib namun dalam pelaksanaannya harus meminimalisir atau menghindarkan potensi terjadinya kegaduhan sehingga dijadikan pilihan. Ukuran dari pertimbangan dilakukan dengan mengaitkan budaya, letak geografis dan aspek sosiologis masyarakat. Ketetapan pemerintah dengan wujud aturan atau kebijakan apapun itu bidangnya menegaskan perlunya muatan konten dan substansi yang meminimalisir potensi terjadinya polemik dan kegaduhan dalam masyarakat. ${ }^{96}$

Keberadaan sekolah bagi guru bukan sekadar tempat mengajar tetapi juga tempat belajar. Setiap guru berkewajiban melakukan peningkatan dan pengembangan kompetensi dan berbagai masalah atau tantangan yang muncul di sekolah dan kelas dijadikan bahan atau pemicu bagi guru untuk belajar. Inovasi dan ide-ide perbaikan pendidikan yang strategik dan aplikatif bisa lahir dari permasalahan dan tantangan tersebut, termasuk kebijakan penguatan karakter sebagai kebijakan full day education dan bukan kebijakan full day school. Orang tua peserta didik dituntut sepenuh hati untuk bekerjasama dengan pihak sekolah dalam membangun komunikasi dan memajukan kualitas pendidikan.

\section{Penutup}

Terjadi sinergisitas antara ketentuan hukum Islam dan konstitusi pemerintah yang berkenaan dengan kebijakan zonasi dan kebijakan penguatan pendidikan karakter. Nalar maslahat dijadikan "pisau" analisis untuk mengekspos kebijakan zonasi dan penguatan pendidikan karakter dengan ilmu alatnya yang bersumber dari qawa'id fiqhiyyah atau norma- norma yang dipergunakan untuk mengeksplorasi pemahaman yang utuh yang selanjutnya bisa dijadikan patokan dan ketetapan yang progresif. Kebijakan apapun yang diterapkan termasuk kebijakan zonasi dan penguatan pendidikan karakter adalah kebijakan yang steril dari polemik atau kebijakan yang substansi maslahatnya lebih besar dari unsur mafsadat-nya (keburukan dan potensi munculnya nilai negatif). Kebijakan zonasi dinilai sebagai kebijakan yang berupaya mengembalikan atau memulihkan kondisi pendidikan. Akses

\footnotetext{
${ }^{96}$ Fauzi Usman Salih, al Qawa"id wa al Dawabit al Fiqhiyyah wa Tatbiqatiha fi al Siyasah al Syar"iyyah, h. 121.
} 
mendapatkan sarana dan fasilitas pendidikan sebelum adanya kebijakan zonasi telah memunculkan sekat-sekat sosial dalam masyarakat. Dikotomi dalam pendidikan terjadi dalam bentuk antara sekolah favorit dan tidak favorit, antara sekolah unggulan dan sekolah pinggiran. Regulasi yang dikeluarkan oleh Kementerian Pendidikan dan Kebudayaan sebagai wakil pemerintah yang mengatur bidang pendidikan dalam bentuk kebijakan zonasi tidak lain untuk merestorasi pendidikan nasional dan menghilangkan dikotomi antar lembaga pendidikan secara bertahap. Kebijakan penguatan pendidikan karakter adalah kebijakan yang bersifat sebagai media dan alat untuk mengembangkan dan meningkatkan kualitas pendidikan. Kebijakan tersebut menjembatani penanaman nilai karakter dari lingkungan keluarga dan penguatan nilai pendidikan karakter yang dijalankan sekolah kepada peserta didik. Wujud formal dari kebijakan penguatan pendidikan dalam bentuk full day school ditransformasikan menjadi full day education sehingga keberadaan sekolah tidak selalu diposisikan sebagai pihak yang bertanggung jawab dalam pendidikan. Full day school diposisikan sebagai alternatif sehingga kualitas pendidikan menjadi tanggung jawab bersama antara orang tua, sekolah dan masyarakat.

\section{Daftar Pustaka}

Arizany, Aan. Berkaca pada Konsep Pendidikan Bapak Bangsa, Koran Seruya pada Rubrik Opini tanggal 24 Juli 2016.

Albuhaniyyah, Abdullah bin Salih bin Muhammad. al Tatbiqat al Tarbawiyyah li Ahammi al Qawa"id al Fiqhiyyah al Kubra. Riyad: alSaud University, 2007 M/1428 H.

Abdu al Salam, Izz al Din bin. Qawa"idal AHkam fi Masalih al Anaam (al Qahirah: Dar al Istiqamah, 1980.

al Utsaimin, Muhammad bin Salih. al Qawa"id al Fiqhiyyah (al Iskandariyyah: Dar al Basirah, $1422 \mathrm{H}$.

Abdullah, Mujiono. Dialektika Hukum Islam dan Perubahan Sosial, Sebuah Refleksi Sosiologis atas Pemikiran Ibnu Qayyim al Jauziyyah. Cet. I; Surakarta: Muhammadiyah University Press, 2003.

al Khallaf, 'Abd al-Wahab. al-Siyasah al Syar"iyyah. al-Qahirah: Dar al Ansar, $1977 \mathrm{M}$

Althoff, Michael Rush Philip. An Introduction to Political Sociology, dialihbahasakan oleh Kartini Kartoni dengan judul: Pengantar Sosiologi Politik. Cet. X; Jakarta: RajaGrafindo Persada, 2003.

al-Subki, Imam Tajuddin 'Abd. Al-Wahab. al-Asybah wa al-Naza"ir. Cet. I; Beirut: Dar al Kutub al Ilmiyyah, 1399 H/1979 M.

al Salam, Izzuddin bin 'Abd Qawa"id al-Ahkam fi Masalih al Anam Juz I. t.t.: Dar al Jail, 1980. Al-Ghazali. al-Mustasfa min „Ilmi al Usul (Mesir: t.pn. tt.

as Said, Muhammad. Filsafat Pendidikan Islam. Cet. I; Jakarta; Mitra Pustaka, 2011. 
al-Marsudi, Subandi. Pancasila dan UUD“45 dalam Paradigma Reformasi. Cet. II; Jakarta; RajaGrafindo Persada, 2001.

Afandy, Susianah. Polemik Sistem Zonasi PPDB di Sekolah, Narasumber dan Komisioner KPAI Bidang Pendidikan di Berita Satu TV, tanggal 11 Juli 2018.

al Salam, Abu Muhammad Izz al Din Abdu al Aziz ibnu Abdi. Qawa"id al Ahkam fi Masalih al Anaam Juz I. Mesir: al Istiqamah, t.th.

Asrori. Perkembangan Peserta Didik Pengembangan Kompetensi Pedagogis Guru. Cet. I; Yogyakarta: Media Akademia, 2015.

al Zuhailiy, Muhammad Mustafa. al-Qawa"id al Fiqhiyyah wa Tatbiqatuha ala al Mazahib al,,Arba"ah Juz II. Dimasyq: Dar al Fikr, 2006 M/1427 H.

Abdu al Baqi, Zadeh Fu'ad. Fathu al Rahman li Talib al Qur"an. Cet. I; Beirut: Dar al Ilmi, $1323 \mathrm{H}$.

al Bukhari, Muhammad bin Ismail. Sahih al Bukhari Jilid VII, Kitab al Adab Bab tentang Mendekap dan Merangkul Anak (Beirut: Dar al Kutub al Ilmiyyah, t.th, Hadis Nomor 6003.

al Buhaniyah, 'Abdullah bin Salih bin Muhammad. al Tatbiqat al Tarbawiyyah li Ahammi al Qawa"id al Fiqhiyyah al Kubra. Saudi: al Imam Muhammad bin Saud al Islamiyyah University, 2007 M/1428 H

Badan Pengembangan dan Pembinaan Bahasa, Kamus Besar Bahasa Indonesia. Jakarta: Kementerian Pendidikan dan Kebudayaan Republik Indonesia, 2000.

Bakr bin Abdullah Zaid, al Qawa"id al Fiqhiyyah al Mustakhrajah min Kitab I"lam al Muwaqqi"in li Al Allamah Ibnu al Qayyim al Jauziyyah. Dimasyq: Dar Ibnu 'Affan, $2000 \mathrm{M}$.

B. Hallaq, Wael. A History of Islamic Legal Theories, diterjemahkan oleh Kusnadiningrat dan Abdul Haris dengan judul: Sejarah Teori Hukum Islam. Jakarta: RajaGrafindo Persada, 2000

Daradjat, Zakiah. Kepribadian Guru. Jakarta: Bulan Bintang, 2000.

Djazuli. Kaidah-Kaidah Fikih, Kaidah-Kaidah Hukum Islam dalam Menyelsaikan Masalah- masalah yang Praktis. Cet. III; Jakarta: Kencana Prenada Media, 2006.

Daulay, Haidar Putra. Pendidikan Islam dalam Sistem Pendidikan Nasional di Indonesia. Cet. I; Jakarta: Prenada Media, 2004.

Effendy, Muhadjir. Polemik Sistem Zonasi PPDB di Sekolah, Narasumber dan Menteri Pendidikan dan Kebudayaan RI Masa Pemerintahan Jokowi - Jusuf Kalla di Berita Satu TV, tanggal 11 Juli 2018

H. M. Asrori. Perkembangan Peserta Didik Pengembangan Kompetensi Pedagogis Guru. Cet. I; Yogyakarta: Media Akademi, 2015.

Hayati. Pentingnya Peran Keluarga dan Masyarakat pada Pendidikan Anak di Sekolah, diakses via kompasiana.com pada tanggal 18 Februari 2019.

Hamzah, Fahri. Full Day Sekolah Meminimalisir Anak Kecanduan Gadget, diakses merdeka.com pada tanggal 7 Maret 2019.

Ibrahim, Ahmad Syauqi. al Ma"arif al Tibbiyyah fi Daw"I al Qur"an wa al Sunnah Juz I. Cet. I; al Qahirah: Dar al Fikr al 'Arabiy, 2002 M/1423 H.

Idrus, Achmad Musyahid. Perkembangan Penalaran Filosofis Hukum Islam. Cet. I; Makassar: Alaluddin University Press, 2013. 
Idrus, Nurul Ilmi. Gaduh Zonasi, Sumber Koran Harian Pagi Fajar Makassar pada Rubrik Opini tanggal 17 Juli 2018.

Imran, Ali. Implementasi Kebijakan Pendidikan. Jakarta: Bumi Aksara, 2008.

Irawan,Adriansyah. Mulai Pendidikan dari Keluarga, Opini dipublikasi di Palopo Pos tanggal 10 Juli 2018

Jessica. Negara-negara Maju dan SIstem Pendidikan yang Diterapkan, diakses educenter.id. pada tanggal 21 Februari 2019.

Jalaluddin. Filsafat Pendidikan Islam: Telaah Sejarah dan Pemikirannya. Cet. II; Jakarta: Kalam Mulia, 2011

Kementerian Pendidikan dan Kebudayaan, Peraturan Menteri Pendidikan dan Kebudayaan Republik Indonesia No. 14 Tahun 2018 Pasal 3, Kemendikbud RI, 2018.

Kementerian Pendidikan dan Kebudayaan RI, Kebijakan Penguatan Pendidikan Karakter, diakses cerdasberkarakter.kemendikbud.go.id pada tanggal 9 Maret 2019.

Karman, Thamrin. Menakar Sistem Zonasi, sebagai Narasumber dan Sesditjen Dikdasmen Kemendikbud RI pada Kompas TV 21 Mei 2018. Koesoema, Doni. Kebijakan Penguatan Pendidikan Karakter Kementerian Pendidikan dan Kebudayaan, presentasi makalah dalam pertemuan nasional MNKP di Malang 6 Oktober 2017.

al Khadmi, Nur al Din Mukhtar. Qawa"id Fiqhiyyah Tunis: Zaytunah University, 2007

Listyarti, Retno. Kisruh dan Polemik Kebijakan Zonasi dalam Penerimaan Peserta Didik Baru, Komisioner Komisi Perlindungan Anak Indonesia Bidang Pendidikan, Sumber Kompas TV dalam acara Sapa Malam Indonesia, Juli 2018.

Moh. Sabri AR. Mewaspadai Gejala Anti Intelektualisme, Koran Harian Pagi Fajar Makassar pada Rubrik Semesta Tanda, tanggal 23 Februari 2018.

Muchtar, Heri Jauhari. Fikih Pendidikan. Cet. III; Bandung: Remaja Rosdakarya, 2012.

Mubarok, Jaih. Kaidah Fiqh - Sejarah dan Kaidah Asasi. Cet. I; Jakarta: RajaGrafindo Persada, 2002.

Massardi, Yudhistira. Polemik Sistem Zonasi dalam PPDB, sebagai Narasumber dan Pemerhati Pendidikan EDUSPEC Indonesia di Berita Satu TV, tanggal 11 Juli 2018.

Mujahidin. Pelibatan Masyarakat untuk Pembelajaran Bermutu, Opini dipublikasi di Harian Palopo Pos, tanggal 2 Mei 2016

Mahmud, Tariq Ra'uf. al Ummu Madrasatu Iza A"dadtaha - A"dadta Sya "ban Tayyiba al A"raq. Diakses dari artikel yang bersumber dari kitabat@kitabat.com pada tanggal 22 Maret 2019.

M. Thalib. 25 Asas Islami Mendidik Anak. Bandung: Irsyad Baitu al Salam, 2001.. Muchtar, Heri Jauhari. Fikih Pendidikan (Cet. II; Bandung: Remaja Rosda Karya, 2012.

Manisi, Samiyah. al Ummu Madrasatun U"la, Makalah diakses dari alukah.net pada tanggal 22 Maret 2019.

Nursalam. Guru dan Peradaban Pendidikan Indonesia, Opini harian Pagi Surat Kabar Fajar tanggal 1 Maret 2017. 
Nasurung, M. Fadlan L. Belajar dari Pesantren, Opini Koran Fajar Harian Pagi Makassar terbit 29 Desember 2018.

Olivia, Firda. Lima Kebijakan Pendidikan yang Pernah Jadi Kontroversi, diakses dari sumber brilio.net pada tanggal 16 Maret 2019.

Pera, Dalasari. Menilai Pendidikan Karakter, Opini Harian Pagi Fajar Makassar terbit tanggal 13 Oktober 2018,

Presiden RI. Peraturan Presiden No, 87 Tahun 2017 tentang Penguatan Pendidikan Karakter Pasal 9 ayat 1-3, Jakarta: Lembaran Negara RI, September 2017.

Qomar, Mujamil. Kesadaran Pendidikan Sebuah Penentu Keberhasilan Pendidikan. Cet. I; Jogjakarta: Ar Ruzz Media, 2012.

Raper, Jan Hendrik. Pengantar Logika Asas-asas Penalaran Sistematis. Yogyakarta: Kanisius,2016.

Republik Indonesia, Undang-Undang Ri Nomor 20 Tahun 2003 tentang Sistem Pendidikan Nasional Bab II Pasal 2.

Rahardjo, Dawam. Ensiklopedi Al-Qur"an Tafsir Sosial Berdasarkan Konsepkonsep Kunci. Cet.I; Jakarta: Paramadina, 1996.

Rifa'I, Muhammad. Sosiologi Pendidikan Struktur dan Interaksi Sosial di dalam Institusi Pendidikan. Cet. I; Jogjakarta: Ar Ruzz Media, 2011.

Syarifuddin, Amir. Garis-garis Besar Fiqh. Cet. I; Jakarta: Prenada Media, 2003..

Sutrisno. Integrasi Keilmuan di Era Rovulsi Industri 4.0, Makalah disampaikan pada Kuliah Umum dalam Pembukaan Kuliah Semester Genap 20182019 di IAIN Palopo, 20 Februari 2019.

Salih, Fauzi Usman. al Qawa"id wa al Dawabit al Fiqhiyyah wa Tatbiqatiha fi al Siyasah al Syar"iyyah. Riyad: Dar al 'Asimah, 2011.

Suprananto, Kusaeri. Pengukuran dan Penilaian Pendidikan. Cet. II; Yogyakarta: Graha Ilmu, 2016.

Suriasumantri, Jujun S. Ilmu dalam Perspektif Sebuah Kumpulan Karangan tentang Hakekat Ilmu. Cet. XIV; Jakarta: Yayasan Obor Indonesia, 1999.

Soerapto. Cita Negara Pancasila, Dmokrasi dan Hak Asasi Manusia. Jakarta: FH-UI, Dokumentasi Presentasi Makalah Seminar Sehari 26 Januari 1995.

Saroni, Mohammad. Pendidikan untuk Orang Miskin Membuka Kran Keadilan dalam Kesempatan Berpendidikan. Cet. I; Jogjakarta: Ar Ruzz Media, 2013.

Suryowati, Estu. Tiga Kebijakan di Bidang Pendidikan yang Dikritik oleh Federasi Serikat Guru, Sumber nasional.kompas.com diakses pada 21 Februari 2019.

Setiawan, Hendro. Manusia Utuh Sebuah Kajian Atas Pemikiran Abraham Maslow. Cet. IV: Yogyakarta: Kanisius, 2014..

Situmorang, Ridwan. Mendukung Kebijakan Zonasi, Opin di Harian Pagi Surakt Kabar Palopo Pos pada tanggal 9 Juli 2018.

Suhadi, Octen. Penguatan Pendidikan Karakter (PPK) untuk Guru dan Siswa SMA/MA. Cet. I; Jakarta Erlangga, 2018.

Supriatin dan Rizki Andwika. Jokowi Teken Perpres Pengganti Peraturan Full Day School, diakses merdeka.com pada tanggal 7 Maret 2019. 
Syuhud, Marsudi. Full Day School dikhawatirkan "matikan" Madrasah Diniyyah, diakses merdeka.com pada tanggal 7 Maret 2019.

Tim Liputan6. Nawacita Pemerintah Jokowi-JK Terkait Pendidikan, diakses liputan6.com tanggal 21 Februari 2019.

W. Leigh, Ronal. Effective Christian Ministry, diterjemahkan oleh Stephen Suleeman dengan judul: Melayani dengan Efektif. Cet. VII; Jakarta: Gunung Mulia, 2007..

Zaid, Bakr bin Abdullah. al Qawa"id al Fiqhiyyah al Mustakhrajah min Kitab I"lam al Muwaqqi"in li Al Allamah Ibnu al Qayyim al Jauziyyah. Dimasyq: Dar Ibnu 'Affan, $2000 \mathrm{M}$.

Zaid, Bakr bin Abdullah. al Qawa"id al Fiqhiyyah al Mustakhrajah min Kitab I"lam al Muwaqqi"in li Al Allamah Ibnu al Qayyim al Jauziyyah. Dimasyq: Dar Ibnu 'Affan, $2000 \mathrm{M}$. 